\title{
Diabetic neuropathy: Summary of treatment options
}

\author{
Haiju H. Chirayath* \\ Medcare Hospital, Dubai, United Arab Emirates
}

Diabetic neuropathy is one of the most common microvascular complications of diabetes and is associated with significant morbidity worldwide. The prevalence of neuropathy is estimated to be about $8 \%$ in newly diagnosed patients and greater than $50 \%$ in patients with longstanding disease [1]. Different classification systems for diabetic neuropathy exist and clinically it can be broadly divided into sensorimotor neuropathy (associated with pain, paraesthesia and sensory loss), cardiovascular autonomic neuropathy (which may contribute to myocardial infarction, malignant arrhythmia and sudden death), gastrointestinal autonomic neuropathy (associated with gastroparesis) and genitourinary autonomic neuropathy (linked with sexual dysfunction and neurogenic bladder) [2].This is a broad subject and the focus of this brief commentary will be the treatment options for this common diabetic complication.

Currently, no drug has been shown in trials to prevent diabetic neuropathy. The Eurodiab Insulin-Dependent Diabetes Mellitus study found that suboptimal glycemic control was associated with the development of diabetic peripheral neuropathy in a large cohort of more than 3,000 people with Type 1 Diabetes [3]. Therefore intensive diabetes therapy is recommended in patients with diabetic neuropathy. The prevention of cardiovascular autonomic neuropathy depends on multifactorial cardiovascular risk reduction and lifestyle intervention [2].

Table 1 lists the various treatment options currently available for treating painful diabetic peripheral neuropathy, along with their

Table 1. Treatment options for painful diabetic peripheral neuropathy.

\begin{tabular}{|l|l|l|}
\hline Class & Medication & Mechanism of Action \\
\hline Tricyclic Anti-depressants & $\begin{array}{l}\text { Amitriptyline, } \\
\text { Desipramine, } \\
\text { Imipramine, } \\
\text { Nortriptyline, }\end{array}$ & $\begin{array}{l}\text { Inhibition of reuptake of } \\
\text { serotonin and/or norepinephrine, } \\
\text { block of sodium channels, } \\
\text { anticholinergic }\end{array}$ \\
\hline GABA Analogues & Gabapentin, Pregabalin \\
\hline $\begin{array}{l}\text { Nerotonin } \\
\text { inhibitors }\end{array}$ & $\begin{array}{l}\text { Decreases release of glutamate, } \\
\text { norepinephrine, and substance } \\
\text { P with ligands on voltage-gated } \\
\text { calcium channels }\end{array}$ \\
\hline Anticonvulsants & $\begin{array}{l}\text { Duloxetine, Paroxetine, } \\
\text { Venlafaxine }\end{array}$ & $\begin{array}{l}\text { Inhibition of both serotonin and } \\
\text { norepinephrine reuptake }\end{array}$ \\
\hline Topical analgesics & $\begin{array}{l}\text { Carbamazepine, } \\
\text { Lamotrigine, } \\
\text { Oxcarbazepine, Sodium } \\
\text { valproate, Topiramate }\end{array}$ & $\begin{array}{l}\text { Inhibition of voltage-gated } \\
\text { sodium channels, resulting in } \\
\text { reduced peripheral nerve } \\
\text { excitability }\end{array}$ \\
\hline Analgesic opiates & $\begin{array}{l}\text { Capsaicin 0.0075\%, } \\
\text { Lidocaine 5\% patch }\end{array}$ & $\begin{array}{l}\text { Desensitization of epidermal } \\
\text { nociceptors and blocking nerve } \\
\text { conduction }\end{array}$ \\
\hline Aldose reductase inhibitor & Morphine, Oxycodone, & $\begin{array}{l}\mu \text {-Receptor agonism, inhibition } \\
\text { of norepinephrine and serotonin } \\
\text { reuptake }\end{array}$ \\
\hline Miscellaneous & $\begin{array}{l}\text { Tramadol } \\
\text { Epalrestat }\end{array}$ & $\begin{array}{l}\text { Inhibition of enzyme associated } \\
\text { with hyperglycemia linked } \\
\text { ischemic nerve injury }\end{array}$ \\
\hline Anti-oxidant \\
\hline
\end{tabular}

mechanism of action. The antioxidant $\alpha$-Lipoic acid administered intravenously is currently the only treatment targeting the pathogenesis of diabetic neuropathy, whereas other treatments focus on symptomatic therapies. A meta-analysis has provided evidence that intravenous treatment with $\alpha$-Lipoic acid is safe and significantly improves both symptoms and neuropathic deficits [4].

Typically, neuropathic pain medications provide limited pain relief. It is therefore important for clinicians to discuss management options and expectations with patients, with the aim of providing clinically meaningful pain relief to patients and improving their quality of life[5].Treatment should be determined based on the patient's clinical history and tolerability of the various medications. If initial treatment is ineffective despite dose titration, it will be necessary to substitute the drug with another one; either from the same or different class.There are no universally accepted first or second line drugs; however various professional bodies have proposed treatment guidelines. The American Academy of Neurology suggests Pregabalin as the first line option with SNRIs (Serotonin Norepinephrine Reuptake Inhibitors),TCAs (Tricyclic Anti-depressants) and opioids as second line choices[6]. Both the European Federation of Neurological Societies (EFNS) and the Neuropathic Pain Special Interest Group of the International Association for the Study of Pain (NeuPSIG IASP) recommend SNRIs, TCAs and GABA (Gamma Amino Butyric Acid) analogues as the first line with opioids as the second line [6].Epalrestat is the only Aldose reductase inhibitor which is licensed in Japan and India based on randomized controlled trials [7]. However, a Cochrane collaboration review of 32 trials comprising 4,970 participants found no overall benefit for this class of drug in treating diabetic neuropathy [8].

Combination therapy with two or more agents has also been explored, but unfortunately there are too few controlled studies on the efficacy of combining drugs. Therefore there are currently no recommendations for combination therapy.

Non-pharmacological approaches are limited and have not been conclusively proven to be effective. Various forms of electrical stimulation have been used to manage pain including percutaneous electrical nerve stimulation and frequency-modulated electromagnetic neural stimulation [5]. Evidence for the benefits of acupuncture in treating neuropathy is limited, but one small trial (in 45 subjects with painful neuropathy)reported an improvement in pain when compared with sham treatment [9]. Emerging therapies for diabetic neuropathy

Correspondence to: Haiju $\mathrm{H}$. Chirayath $\mathrm{PhD}, \mathrm{MSc}, \mathrm{MRCP}(\mathrm{UK})$, Medcare Hospital, Dubai, United Arab Emirates, E-mail: haiju.chirayath@gmail.com

Key words: diabetes, diabetic neuropathy, diabetic complications, neuropathy, neuropathy treatment

Received: March 12, 2017; Accepted: March 22, 2017; Published: March 27, 2017 
include treatment based on endothelial progenitor cells [10] and mesenchymal stem cells[11] although these options are currently in the experimental stage.

In summary, the treatment of diabetic neuropathy involves both prevention (through better glycemic control) as well as pain relief through a number of different classes of drugs. Although treatment options are currently limited, it is hoped that ongoing research will reveal new therapeutic targets in treating this frequently occurring and challenging complication of diabetes.

\section{References}

1. Boulton AJ, Vinik AI, Arezzo JC, Bril V, Feldman EL, Freeman R, et al. (2005) Diabetic neuropathies: a statement by the American Diabetes Association. Diabetes Care28: 956-962. [Crossref]

2. Deli G, Bosnyak E, Pusch G, Komoly S, Feher G (2013) Diabetic neuropathies: diagnosis and management. Neuroendocrinology 98:267-280. [Crossref]

3. Tesfaye S, Stevens LK, Stephenson JM, Fuller JH, Plater M, Ionescu-Tirgoviste C, et al. (1996) Prevalence of diabetic peripheral neuropathy and its relation to glycaemic control and potential risk factors: the EURODIAB IDDM complications study. Diabetologia 39: 1377. [Crossref]
4. Ziegler D, Nowak H, Kempler P, Vargha P, Low PA (2004) Treatment of symptomatic diabetic polyneuropathy with the antioxidant alpha-lipoic acid: a meta-analysis. Diabet Med 21: 114-121. [Crossref]

5. Javed S, Alam U, Malik RA (2015) Treating diabetic neuropathy: Present strategies and emerging solutions. Rev Diabet Stud12:63-83. [Crossref]

6. Spallone V (2012) Management of painful diabetic neuropathy: guideline guidance or jungle? Curr Diab Rep 12:403-413. [Crossref]

7. Goto Y, Hotta N, Shigeta Y, Sakamoto N, Kikkawa R (1995) Effects of an aldose reductase inhibitor, epalrestat, on diabetic neuropathy. Clinical benefit and indication for the drug assessed from the results of a placebo-controlled double- blind study. Biomed Pharmacother 49:269-277. [Crossref]

8. Chalk C, Benstead TJ, Moore F (2007) Aldose reductase inhibitors for the treatment of diabetic polyneuropathy. Cochrane Database Syst Rev 4:CD004572. [Crossref]

9. Garrow AP, Xing M, Vere J, Verrall B, Wang L, Jude EB (2014) Role of acupuncture in the management of diabetic painful neuropathy (DPN): a pilot RCT. Acupunct Med 32:242-249. [Crossref]

10. Jeong JO, Kim MO, Kim H, Lee MY, Kim SW, Li M,et al. (2009) Dual angiogenic and neurotrophic effects of bone marrow-derived endothelial progenitor cells on diabetic neuropathy. Circulation 119:699-708. [Crossref]

11. Bernardi S, Severini GM, Zauli G, Secchiero P (2012) Cell-based therapies for diabetic complications. Exp Diabetes Res 2012.

Copyright: (C2017 Chirayath HH. This is an open-access article distributed under the terms of the Creative Commons Attribution License, which permits unrestricted use, distribution, and reproduction in any medium, provided the original author and source are credited. 